\title{
Perbandingan Hasil Belajar Biologi Model Problem Based Learning Berbantuan LKPD Pokok Bahasan Tulang dan Otot
}

\author{
Nurfathurrahmah ${ }^{1}$, Erni Suryani ${ }^{2}$, Nehru $^{3}$ Olahairullah $^{4}$ \\ 1,2,3,4 Dosen Program Studi Pendidikan Biologi, STKIP Bima. Jalan Piere Tendean Kel. Mande Tel. \\ Fax (0374) 42801, Bima 84191, Indonesia. \\ Email: ernisuryani bio@stkipbima.ac.id
}

\begin{abstract}
Abstrak
Penelitian bertujuan melihat perbandingan hasil belajar biologi model problem based learning berbantuan LKPD pada pokok bahasan tulang dan otot. Jenis penelitian yaitu eksperimen PreExsperimental Designs Sampel penelitian kelas VIII-5 SMP Negeri 1 Kota Bima sebanyak 32 Peserta didik didesain secara Intact-Group Comparison. Berdasarkan hasil analisi data menggunakar rumus uji t, dimana nilai t-hitung lebih besar nilai t-tabel $(-0,43 \leq 3,1)$ atau HO diterima sedangkan Ha ditolak dapat dinyatakan tidak terdapat perbandingan antara hasil belajar biologi model problem based learning berbantuan LKPD pada pokok bahasan tulang dengan hasil belajar biologi model problem based learning berbantuan LKPD pada pokok bahasan otot. Namun jika dilihat secara spesifik dari nilai rata-rata dan jumlah peserta didik mendapat nilai tertinggi (interval 85 - 100) lebih tinggi pada hasil belajar pokok bahasan otot. Hal ini menunjukkan bahwa terdapat perbandingan pencapaian hasil belajarnya.
\end{abstract}

Kata Kunci: Hasil Belajar, Model Problem Based Learning, LKPD, Tulang, Otot.

\section{PENDAHULUAN}

Pembelajaran abad 21 akhir-akhir ini gencar dilakukan disetiap elemen pendidikan baik pada tingkat sekolah dasar hingga pada perguruan tinggi. Hal senada dengan pernyataan Pamungkas (2021) Pembelajaran abad 21 dirancang untuk generasi abad 21 agar mampu mengikuti arus perkembangan teknologi terbaru. Maka dari itu guru sebagai ujung tombak pengembang manusia harus tahu mengenai perkembangan dan perubahan zaman. Murti (2015) dalam Andriyani, Y., dkk (2019) mengungkapkan bahwa di abad ke 21 ini, pendidikan menjadi semakin penting untuk menjamin peserta didik memiliki keterampilan belajar dan berinovasi, keterampilan menggunakan teknologi dan media informasi, serta dapat bekerja, dan bertahan dengan menggunakan keterampilan untuk hidup (life skills).

Menunjang tujuan tersebut diperlukan tanggung jawab semua pihak yang terlibat dalam pendidikan, utamanya pendidik sebagai ujung tombak untuk meningkatkan mutu pendidikan baik dalam merancang pembelajaran, penerapan pendekatan, strategi, metode dan model pembelajaran bahkan menjadi sumber belajar langsung bagi peserta didik sehingga tercapainya tujuan pembelajaran sesuai prinsip dasar pembelajaran abad 21, yaitu Creativity and Innovation, Collaboration, Communication, Critical Thinking and Problem Solving.

Pembelajaran yang sesuai prinsip dasar abad 21 dapat diterapkan di SMP Negeri 1 Kota Bima, dikarenakan sekolah tersebut telah 
menerapkan Kurikulum 2013 dalam setiap matapelajaran, merupakan salahsatu sekolah menengah pertama terbaik di Kota Bima, serta sumber dan fasilitas belajar yang memadai serta didukung hasil wawancara dengan guru matapelajaran biologi bahwa dalam proses pembelajaran ada beberapa metode pembelajaran yang sudah diterapkan diantaranya metode ceramah, Tanya jawab baik secara individu maupun dalam bentuk presentasi kelompok, metode eksperimen yang mengikuti isi dari buku paket yang digunakan oleh guru dan peserta didik. Namun secara implisitnya model pembelajaran belum sepenuhnya diterapkan mengingat keterbatasan pengalaman dari pendidik terkait model pembelajaran yang tepat dalam memotivasi dan menggali potensi belajar yang dimiliki peserta didik serta kekhawatiran tidak tercapainya ketuntasan belajar. Permasalah lain di Indonesia khususnya pada mata pelajaran IPA perkembangan pendidikan masih berada pada kategori rendah (Herman, dkk, 2019).

Hal inilah yang mendasari peneliti menerapkan model pembelajaran problem based learning dikarenakan banyaknya kelebihan yang berpengaruh terhadap keberhasilan peserta didik dalam belajar, yaitu latihan dalam bentuk pertanyaan yang mengaitkan antara materi yang dipelajari dengan situasi nyata dalam kehidupan sehari- hari (otentik) yang bersifat terbuka untuk diselesaikan oleh peserta didik untuk mengembangkan keterampilan berpikir, keterampilan menyelesaikan masalah, keterampilan social, keterampilan untuk belajar mandiri dan membangun pengetahuan baru. Selaras dengan penelitian Suratini (2020) aktivitas belajar peserta didik melalui problem based learning meningkat hal ini dikarenakan peserta didik diberi masalah dan harus bekerja mencari menyelesaikan masalah dengan bereksperimen, dirangsang dengan pertanyaan dan pernyataan berdasarkan hasil eksperimen.

Menunjang kemudahan dalam menerapkan model problem based learning dalam penelitian ini dikombinasi dengan Lembar Kerja Peserta Didik (LKPD) berisikan uraian singkat, langkah kerja serta pertanyaan tentang pokok bahasan tulang dan otot. Adanya LKPD dirasa tepat membantu melatih, mengembangkan keterampilan serta memudahkan peserta didik memiliki pedoman menyelesaikan pertanyaan-pertanyaan, serta mengingat cakupan pokok bahasan tulang dan otot sangat luas pembahasannya. Menurut Lusiana dan Yohandri (2020) LKPD merupakan salah satu sumber belajar yang dapat dikembangkan oleh pendidik sebagai fasilitator dalam kegiatan pembelajaran, membantu pendidik untuk mengaktifkan serta memancing pengetahuan peserta didik dalam 
proses pembelajaran sehingga berlangsung berorientasi kepada peserta didik.

Berdasarkan uraian tersebut penelitian ini melihat perbandingan hasil belajar biologi model problem based learning berbantuan LKPD pada pokok bahasan tulang dan otot. Rumusan masalah dalam penelitian ini apakah ada perbandingan hasil belajar biologi model problem based learning berbantuan LKPD pada pokok bahasan tulang dan otot.

\section{METODE}

Jenis penelitian yaitu eksperimen PreExsperimental Designs. Dilaksanakan bulan Agustus sampai September 2020 pada kelas VIII-5 semester ganjil. Populasi dan sampel sebanyak 32 peserta didik dikarenakan desain penelitian yang dilakukan adalah Intact-Group Comparison, terdapat satu kelompok yang digunakan untuk penelitian tetapi dibagi dua yaitu setengah kelompok (16 peserta didik) untuk eksperimen (model PBL berbantuan LKPD tulang) dan setengahnya (16 peserta didik) untuk kelompok untuk eksperimen (model PBL berbantuan LKPD otot) yang bertujuan untuk mengetahui perbandingan hasil belajar. Instrument berupa soal tes uraian dengan teknik analisi data secara deskriptif kuantitatif kemudian dianalisis inferensial untuk pengujian hipotesis dengan rumus uji t.

\section{HASIL DAN PEMBAHASAN}

Hasil analisis data dari kedua sampel dapat dirangkum dalam tabel berikut:

Tabel 1. Kategori Hasil Belajar Biologi Peserta Didik Kelas VIII5 Model Problem Based Learning Berbantuan LKPD pada Pokok Bahasan Tulang dan Otot

\begin{tabular}{cccccc}
\hline \multirow{2}{*}{ Interval } & \multicolumn{2}{c}{$\begin{array}{c}\text { Berbantuan LKPD } \\
\text { pokok bahasan tulang }\end{array}$} & \multicolumn{2}{c}{$\begin{array}{c}\text { Berbantuan LKPD } \\
\text { pokok bahasan otot }\end{array}$} & \multirow{2}{*}{ Kategori } \\
\cline { 2 - 5 } & Frekuensi & Persentase (\%) & Frekuensi & Persentase (\%) & \\
\hline $0-34$ & 0 & 0 & 0 & 0 & Sangat rendah \\
$35-54$ & 2 & 10 & 1 & 5 & Rendah \\
$55-64$ & 4 & 25 & 2 & 10 & Sedang \\
$65-84$ & 7 & 50 & 8 & 55 & Tinggi \\
$85-100$ & 3 & 15 & 5 & 30 & Sangat tinggi \\
Jumlah & 16 & 100 & 16 & 100 & \\
\hline
\end{tabular}

Jika dikategorikan pada pedoman kategori tinggi. Untuk dapat melihat perbandingan Depdikbud, maka hasil belajar peserta didik dilihat secara uji signifikant serta menentukan hipotesis, dari nilai persentase terbesar dapat dinyatakan pada maka dapat ditampilkan pada tabel berikut ini 
Tabel 2. Rekapitulasi Analis Data Perbandingan Hasil Belajar Biologi Model Problem Based Learning Berbantuan LKPD pada Pokok Bahasan Tulang dan Otot.

\begin{tabular}{|c|c|c|}
\hline Komponen Data & $\begin{array}{l}\text { Kelas model problem based learning } \\
\text { berbantuan LKPD pada pokok bahasan } \\
\text { tulang }\end{array}$ & $\begin{array}{c}\text { Kelas model problem based learning } \\
\text { berbantuan LKPD pada pokok } \\
\text { bahasan otot }\end{array}$ \\
\hline Nilai tertinggi & 88 & 70 \\
\hline Nilai terendah & 42 & 54 \\
\hline Rata-rata & 66 & 71 \\
\hline Standar deviasi & 12,92 & 10.19 \\
\hline T tabel & \multirow{2}{*}{\multicolumn{2}{|c|}{$\begin{array}{c}3,1 \\
-0,43\end{array}$}} \\
\hline T hitung & & \\
\hline
\end{tabular}

Berdasarkan hasil analis data, hasil belajar peserta didik yang diterapkan model problem based learning berbantuan LKPD pada pokok bahasan tulang nilai tertinggi sebesar 88 dan nilai terendah 42 dengan persentase $50 \%$ dibandingkan hasil belajar peserta didik yang diterapkan model problem based learning berbantuan LKPD pada pokok bahasan otot nilai tertinggi sebesar 70 dan nilai terendah 54 dengan persentase 55\% keduanya dikategorikan tinggi dari 16 peserta didik.

Jika dilihat perhitungan menggunakar rumus uji $\mathrm{t}$, dimana nilai t-hitung lebih besar nilai t-tabel $(-0,43 \leq 3,1)$ atau H0 diterima sedangkan ha ditolak dapat dinyatakan tidak terdapat perbedaan antara hasil belajar biologi model problem based learning berbantuan LKPD pada pokok bahasan tulang dengan hasil belajar biologi model problem based learning berbantuan LKPD pada pokok bahasan otot. Namun jika dilihat secara spesifik dari nilai rata-rata dan jumlah peserta didik mendapat nilai tertinggi (interval $85-100$ ) lebih tinggi pada hasil belajar pokok bahasan otot. Hal ini menunjukkan bahwa terdapat perbedaan atau terdapat perbandingan pencapaian hasil belajarnya.

Pada dasarnya model problem based learning berbantuan LKPD sangatlah membantu dalam memngembangkan kemampuan peserta didik dalam memahami materi yang dipelajarinya apalagi didukung oleh lembar kerja peserta didik untuk menfasilitasi dalam penyelesaian soal yang diberikan. Senada dengan kesimpulan penelitian Andriyani. N, dkk, (2021) terdapat peningkatan keaktifan mental belajar siswa melalui model pembelajaran problem based learning berbantuan LKPD live worksheet. LKPD yang dikembangkan dapat meningkatkan hasil creative thingking skill (kompetensi pengetahuan, sikap dan keterampilan) peserta didik, Sahida (2018).

\section{KESIMPULAN}

Kesimpulan dalam penelitian ini : Nilai thitung lebih besar nilai t-tabel $(-0,43 \leq 3,1)$ atau H0 diterima sedangkan Ha ditolak menunjukkan tidak terdapat perbandingan antara hasil belajar biologi model problem based learning berbantuan LKPD pada pokok bahasan tulang dengan hasil 
belajar biologi model problem based learning berbantuan LKPD pada pokok bahasan otot.

\section{DAFTAR PUSTAKA}

Andriani, Y., \& Rusman. (2019). Implementasi Pembelajaran Abad 21 dalam Kurikulum 2013. Jurnal Penelitian Ilmu Pendidikan Volume 12, Nomor 1, Maret 2019.

Andriyani, N., Hanafi, Y., Safitri, I.Y.B., \& Hartini, S. (2021). Penerapan Model Problem Based Learning Berbantuan LKPD Live Worksheet untuk Meningkatkan Keaktifan Mental Siswa pada Pembelajaran Tematik Kelas VA SD Negeri Nogopuro. Prosiding Pendidikan Profesi Guru Fakultas Keguruan dan Ilmu Pendidikan, Universitas.

Herman., Nurfathurrahmah., Rubianti, I., \& Bakhtiar. (2019). Model Pembelajaran Inkuiri Terbimbing Terhadap Kemampuan Berpikir Kritis Peserta Didik MTs Darul Hikmah Kota Bima. Jurnal Biotek, Volume 7, No 2 Tahun 2019.

Lusiana., \& Yohandri. (2020). Efektivitas Penggunaan Lembar Kerja Peserta Didik (LKPD) Berbasis Model Project Based Learning Berbantuan Aplikasi Tracker dengan Pendekatan Saintifik pada Materi Gerak Harmonis Sederhana. Jurnal Penelitian dan Pembelajaran Fisika, Vol 6, No 2.

Pamungkas, B. (2021). Pembelajaran Abad 21. https://www.tripven.com/pembelajaranabad-21/. Diakses Tanggal 2 Agustus 2021.

Sahida, D. (2018). Pengembangan Lembar Kerja Peserta Didik Berbasis Problem Based Learning Berbantuan Komik untuk Meningkatkan Creative Thinking Skill Peserta Didik pada Materi Gerak Lurus. Jurnal Eksata Pendidikan (JEP), Volume 2, Nomor 1, Mei 2018.
Suratini. (2020). Penerapan Problem Based Learning Berbantuan LKPD pada MateriMateri Pencemaran Lingkungan. Jurnal Penelitian Pendidikan Indonesia (JPPI), Vol 5, No 2 Mei-Agustus 2020. 